\title{
In Memoriam: Emeritus Professor Sue (Margaret Susan) Povey [1942-2019]
}

\section{Rosemary Ekong}

Department of Genetics, Evolution \& Environment, University College London, UK.

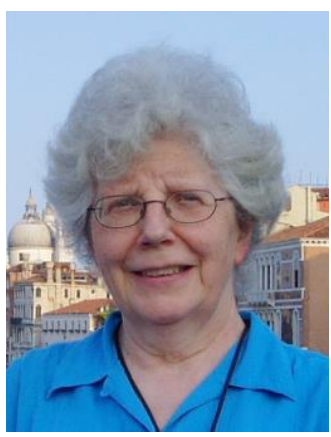

Margaret Susan Povey, or Sue, as she liked to be called, passed away on $11^{\text {th }}$ January 2019. Sue was a research scientist who made her mark in many different areas of human genetics: gene mapping, gene nomenclature, genetic variation and disease, and until her death, the disease tuberous sclerosis complex. As well as an active research programme, Sue held many positions of responsibility among which were Deputy Director of the MRC Human Biochemical Genetics Unit (1998-2000); Council Member of Human Genome Organisation (HUGO) (1996-2000), Member of UK MRC Molecular \& Cellular Medicine Board (19972000), Vice president of HUGO Europe (1999-2005), Member of Wellcome Trust Molecular and Cell Panel (2001-2005), Editor in Chief of Annals of Human Genetics (2000-2007), Tuberous Sclerosis Association Medical Advisors' panel (till 2019), and Trustee/Director for HUGO London (1999-2019). She also held the prestigious title Haldane Professor of Human Genetics from 2000-2007.

Sue was born in 1942 in Leeds to Jack Povey, an RAF intelligence officer during the Second World War, and his wife, Margaret (nee Robertson), the first woman to graduate from Leeds Medical School. Sue's father later established the physics department at St Michael's college, currently Mount St Mary's Catholic high school, in Leeds, and Sue's mother was a paediatrician who managed a maternity hospital in Leeds.

Sue was educated at Notre Dame Collegiate School in Leeds, Girton College - University of Cambridge where she graduated in genetics in 1964, and University College London (UCL) where Sue qualified in medicine in 1967. Sue's work as a junior doctor (1967-1968) included placements in UCL and Huddersfield, followed by a one-year service with Save the Children Fund in Algeria. On occasion, Sue recalled how her father had spotted that she would not be happy as a clinician and encouraged her to do research. Sue would end this recollection with, "and he was right!".

Sue's long and distinguished research career in human genetics goes back to 1970 when she first joined the Medical Research Council, Human Biochemical Genetics unit at UCL, as a staff member in Harry Harris's group. Prior to the publication of the sequence of the human 
genome, and working with several collaborators, both national and international, Sue successfully mapped many human genes to specific chromosomes using somatic cell hybrids. She participated in all the Human Gene Mapping Workshop meetings and chaired some of the committees (1975-1991), eventually focusing on Workshops on chromosome 9 (1992-2000) on which the TSC1 gene was eventually identified.

During Sue's gene mapping days, she experienced a personal tragedy when her beloved niece passed away from liver disease as a consequence of alpha-1-antitrypsin (A1AT) deficiency, aged 13 years. This experience not only drove her to research on $A 1 A T$ deficiency and deliver on a prenatal diagnostic test, but it also reinforced her 'patients and their families first' ethos.

With the identification of many human genes came the need for systematic name assignment. Sue became chair of the International Human Genome Organisation (HUGO) Gene Nomenclature Committee (HGNC) in 1996, having taken over from Phyllis McAlpine. Though Sue found gene nomenclature challenging due to the passion with which scientists treasured the names they had assigned genes they discovered, she persisted. Elspeth Bruford, who has continued the activities of the HGNC upon Sue's official retirement in 2007, recalls how Sue often repeated a quote attributed Michael Ashburner at Cambridge that "biologists would rather share their toothbrush than share a gene name". During the eleven years of Sue's tenure as chair of HGNC, over 20,000 names and symbols were assigned to human genes. Funding for her HGNC team was secured from the US Department of Energy, the US National Institutes of Health, the UK Medical Research Council and the Wellcome Trust.

Sue was involved with this journal, Human Mutation, as a Communicating Editor during 2007-2010 and also as a frequent reviewer and author. She wrote or co-authored 12 articles in this journal, including seminal papers on TSC1 and TSC2 biological function and databases, and also valuable standards papers on locus-specific database construction and curation. She also contributed uniquely to Online Mendelian Inheritance in Man (OMIM; https://www.omim.org/) during her tenure as HGNC chair, coordinating closely with Victor J. McKusick and the OMIM writers and editors to assist the medical genetics research community in promoting adherence to HGNC nomenclature standards.

Sue spent the last 34 years of her life working on tuberous sclerosis complex (TSC), among other things. Her involvement with TSC came about from an attendance at a seminar delivered by John Osborne in UCL. John Osborne ran a TSC clinic in Bath and had come to UCL "pleading" (as Sue always said) for someone to work on TSC. Coincidentally, Malcolm Ferguson-Smith at the Duncan Guthrie Institute of Medical Genetics in Glasgow had some data on the ABO blood group in TSC at about the same time. Sue got interested and, in 1985 , she received details and samples from 32 families which were analysed for biochemical markers in her laboratory. Through pooling results with Glasgow, it became evident that the gene in some families with TSC was linked to the ABO blood group on chromosome 9.

The subsequent discovery of patients with TSC, within a different family, where the causal gene could not be linked to the ABO blood group locus, led to confirmation of a second TSC 
gene (TSC2) and its identification on chromosome 16 in 1993 by Julian Sampson and others. Sue's research group, together with that of Jonathan Wolfe (at UCL) embarked on positional cloning and reconstructed a $1.7 \mathrm{MB}$ sequence of overlapping cosmid contigs that covered the TSC1 gene region on chromosome 9q34. Sue's attitude to collaborative research for the common good was again evident in her willingness to share the cosmid clones with collaborators as there was now a consortium of researchers in USA, Holland, Poland, Bath, Cambridge and Cardiff.

The policy of the Human Genome Project sequencing at the Whitehead Institute, to publish sequences daily, created a lot of competition. Sue's group was able to determine the orientation of the 1.7MB TSC1 gene region which guided the direction in which to search for the TSC1 gene. Without hesitation, Sue shared this information with other consortium members. Within a few months, David Kwiatkowski informed consortium members that many of his patients had changes in one specific gene, a finding that was replicated by Sue's group and other consortium members over Easter 1997. The initial finding of the gene and confirmation within a space of three days led Sue to remark that "Some of these researchers, well, they don't seem to go to sleep, ever!" As can be imagined, there was a lot of excitement and 'secrecy' prior to Sue's interview by the BBC, and members of Sue's group had to find some contrived excuse why they had given up their Easter holidays.

With both TSC genes identified, and no strong indication for a third TSC gene, Sue turned her attention to understanding variation in the sequence of the TSC1 and TSC2 genes and its links to the development, signs and symptoms of TSC. With funding from the Tuberous Sclerosis Alliance (USA) and the Tuberous Sclerosis Association (UK), Sue set up the TSC variation databases in 2005, a worldwide resource on variations in both TSC genes which we continue to manage and update with new findings. Over 4,000 different genetic changes in the TSC genes have been rigorously and painstakingly assessed for their involvement in causing TSC. The TSC databases, used daily by TSC researchers, clinical geneticists, and patients globally, is an essential resource to guide the interpretation of genetic test results for patients and families with TSC, and is regarded as a trusted data source for TSC research conducted worldwide. Sue also contributed to the TSC diagnostic criteria update published in 2012.

Not unrelated to Sue's focus on patients, was her contribution to the UK Prime Minister's Questions (PMQs) on October $26^{\text {th }} 2016$, specifically on the policy of NHS England not routinely funding Everolimus for inoperable brain tumours (subependymal giant cell astrocytoma, SEGA) in TSC. A combination of Sue's invitation to the House of Commons for 'Tea and Scones on the Commons Terrace' one week prior, and Sue's letter to John Bercow the Speaker of the House of Commons, led to Greg Mulholland (Member of Parliament at the time) asking his question during PMQs; and the PM Theresa May agreeing a meeting with Greg Mulholland, the TSA and members of the TSC community for discussions on a way forward over NHS England's policy on Everolimus for inoperable SEGA. Barely one month later, in November 2016, NHS England routinely commissioned the use of Everolimus for SEGA associated with TSC!

Sue participated in the initial 2006 and subsequent biennial meetings of the Human Variome Project (HVP) until 2012. Its mission, "to ensure that all information on genetic variation and 
its effect on human health can be collected, curated, interpreted and shared freely and openly", agreed firmly with Sue's goal of sharing data for the benefit of other patients, diagnostics and research, while at the same time maintaining the privacy and confidentiality of patients and their families. In this regard, Sue chaired a working group of the HVP that developed practical guidelines to address ethical issues relating to the curation of variation databases, published in 2010. Sue also worked with Donna Maglott at The National Center for Biotechnology Information (NCBI) where the TSC databases served as a pilot for defining sequences for variation description, and data sharing between locus-specific databases and genome databases.

Many who worked with Sue in various capacities attest to her many qualities, including upholding standards and a formidable critique of research proposals, but at the same time, Sue was a very kind and compassionate person; some of these recollections can be viewed at https://www.ucl.ac.uk/biosciences/news-sue-povey-comments.pdf. Sue took great interest in the personal development of those who worked with her and would 'go the extra mile' to ensure that the individual was given recognition for their work.

Sue loved her dogs, birds, flowers, gardening and walks. She kept bird feeding stations in her garden and maintained an array of bird feed to ensure she never ran out. During the flowering season Sue always came into the office with sweet pea flowers from her garden which she gave to colleagues. In the later months of 2018, Sue would still go outdoors for walks with her beloved dog Jake, who survived her.

Sue leaves behind her brother, Phil; nephew, Ian; many scientific colleagues and friends.

Sue (Margaret Susan) Povey, human geneticist, born 24 April 1942; died 11 January 2019 